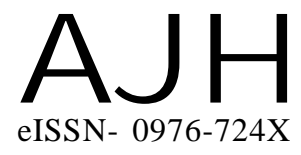

Article history :

Received : 26.08.2016

Revised : 17.11.2016

Accepted : 27.11.2016
Members of the Research Forum

Associated Authors:

${ }^{1}$ Department of Horticulture, Faculty of Agriculture, Annamalai

University, Annamalai Nagar, CHIDAMBARAM (T.N.) INDIA

Author for correspondence : E. ARIVAZHAGAN

Department of Horticulture, Faculty

of Agriculture, Annamalai

University, Annamalai Nagar,

CHIDAMBARAM (T.N.) INDIA
THEASIAN JOURNAL OF HORTICULTURE

Volume 11 | Issue 2 | December, 2016 | 396-400

Visit us -www.researchjournal.co.in

RESEARCH PAPER

DOI : 10.15740/HAS/TAJH/11.2/396-400

\title{
Influence of plant growth regulators and Azospirillum on survival percentage of transplanted air layers in guava (Psidium guajava L.)
}

\section{ANANDHANAMBI ${ }^{1}$, E. ARIVAZHAGAN AND R. KANDASAMY ${ }^{1}$}

ABSTRACT : Investigation was carried out on air layering in guava as influenced by growth regulators and Azospirillum was carried out in the Orchard, Department of Horticulture, Faculty of Agriculture, Annamalai University, Annamalai Nagar during 2013-14, aimed to find out optimum concentration for maximum survival percentage in mature shoot air-layers of guava cv. L-49. There are 14 treatment combinations with three replications laid out in Randomised Block Design. With regard to survivability of rooted layers, maximum survival percentage $(98.14 \%, 60$ days after separation) was noted in the layers treated with Azospirillum $37.5 \mathrm{~g}+$ IBA $3000 \mathrm{ppm}$ + NAA $3000 \mathrm{ppm}\left(\mathrm{T}_{12}\right)$.

KEY WORDS : Plant growth regulator, Azospirillum, Guava, Rooting

HOW TO CITE THIS ARTIClE : Anandhanambi, D., Arivazhagan, E. and Kandasamy, R. (2016). Influence of plant growth regulators and Azospirillum on survival percentage of transplanted air layers in guava (Psidium guajava L.). Asian J. Hort., 11(2) : 396-400, DOI : 10.15740/HAS/TAJH/11.2/396-400. 